\title{
(Bio)ethics for all beings: a proposal under construction
}

\author{
(Bio)ética para todos os seres: uma proposta em construção \\ (Bio)ética para todos los seres: una propuesta en construcción
}

Received: 10/27/2021 | Reviewed: 11/06/2021 | Accept: 12/03/2021| Published: 12/04/2021

\author{
Verônica Ribeiro Possamai \\ ORCID: https://orcid.org/0000-0001-9277-7842 \\ Universidade Federal do Rio de Janeiro, Brazil \\ E-mail: vrpossamai.fono@gmail.com
}

\begin{abstract}
(Bio)ethics for all beings is under construction as a theoretical framework - proposed by R. Siqueira-Batista - that has as its origin the ethics for all beings. It is based on fundamentals such as quiddity, totality, interdependence, and has its central principle in the laic compassion. It has applicability in bioethical conflicts involving end of life (euthanasia), environmental ethics and public health / Primary Health Care. This study was carried out based on articles on the (bio)ethics of all beings and aims to present the reflection about the nomenclature; to define the main foundations; and analyze its applicability. It was concluded that the (bio)ethics of all beings is a bioethical current that can be applied in different fields, as it defends a careful and affectionate look towards human and non-human beings, living and non-living.
\end{abstract}

Keywords: Bioethics; Ethic; Laic compassion; Ethics for all beings.

\section{Resumo}

A (Bio)ética para todos os seres está em construção como uma corrente teórica - proposta por R. Siqueira-Batista que tem como origem uma ética para todos os seres. É baseada em fundamentos como quididade, totalidade, interdependência, e tem seu princípio central na compaixão laica. Apresenta aplicabilidade em conflitos bioéticos que envolvem fim de vida (eutanásia), ética ambiental e saúde pública / Atenção Primária à Saúde. Este estudo foi realizado baseado em artigos sobre a (Bio)ética de todos os seres e tem objetivo de apresentar a reflexão acerca da nomenclatura; definir os fundamentos principais; e analisar sua aplicabilidade. Concluiu-se que a (Bio)ética de todos os seres é uma corrente bioética que pode ser aplicada em diversos campos, pois defende um olhar cuidadoso e afetuoso para com os seres humanos e não humanos, vivos e não vivos.

Palavras-chave: Bioética; (Bio)ética para todos os seres; Compaixão laica; Ética.

\section{Resumen}

La (Bio)ética para todos los seres se está construyendo como una corriente teórica - propuesta por R. Siqueira-Batista - que tiene como origen una ética para todos los seres. Se basa en fundamentos como la talidad, la integridad, la interdependencia y tiene su principio central en la compasión laica. Presenta aplicabilidad en conflictos bioéticos relacionados con el fin de la vida (eutanasia), la ética ambiental y la salud pública / Atención Primaria de Salud. Este estudio se realizó a partir de artículos sobre la (Bio)ética de todos los seres y tiene como objetivo presentar la reflexión sobre la nomenclatura; definir los principales fundamentos; y analizar su aplicabilidad. Se concluyó que la (Bio)ética de todos los seres es una corriente bioética que se puede aplicar en diferentes campos, ya que defiende una mirada cuidadosa y afectuosa hacia los seres humanos y no humanos, vivos y no vivos.

Palabras clave: Bioética; (Bio)ética para todos los seres; Compasión laica; Ética.

\section{Introduction}

(Bio)ethics for all beings is a current theoretical still under construction. Its origins can be retrieved from the initial formulation of an ethics for all beings, which was developed around the concept of laic compassion - applied to ethical issues at the end of life (Siqueira-Batista, 2009) -, with the use of from Quantum Mechanics as a metaphor (Siqueira-Batista, 2008) and in an articulated way to deep ecology (Naess, 1973, 1989; Siqueira-Batista et al., 2009).

The transition from ethics to (bio)ethics is justified by the recognition of the relationship between that field and bioethics. Ethics corresponds to the investigation of the judgment of qualified acts as pairs of opposites "right and wrong", "correct and incorrect" and "fair and unfair" (Abbagnano, 2007), which implies in questioning the conceptual differences between moral and ethics. Moral correspond to the "rule" that regulates the behavior of certain human groups, while ethics 
promotes reflection - established by critical reason - about the aforementioned "rule" (Mora, 1967). Regarding the concept of bioethics, this can be sought in three authors (Siqueira-Batista et al., 2021): (1) Fritz Jahr, from 1927, called Bio-Ethik, had characterized bioethics as an ethical obligation that should not be directed only to human beings, but to all living beings (Goldim, 2004); (2) Van Rensslaer Potter, 1970, proposes a new ethics aimed at the perpetuation of the human species, that is, a science of survival (Potter, 1970); and (3) André Hellegers, who proposes an extension of medical ethics, uniting ethics and biology, creating a new medical ethics, giving rise to the name of the Joseph and Rose Kennedy Institute for Human Reproduction and Bioethics (Goldim, 2016). Based on the above definitions, Siqueira-Batista defines bioethics as:

“(...) an epistemic area that emerged from the effort to find answers to the changes and challenges that emerged in the 20th (and 21st) century, in the spheres of health, life and environmental sciences, putting on the agenda the respect for existence, care and protection of living beings - all, human or not - and their natural habitat". (Siqueira-Batista, 2020, p. 260)

The relationship between ethics and bioethics has been defined in different ways, sometimes converging and sometimes divergent, as well discussed by Siqueira-Batista (2020). Reich claims that bioethics is classified as one of the ethics applied by the Western ethical tradition (Reich, 1995). In this way, bioethics would be a subset of applied ethics. However, as explained above, there are several definitions and positions on these concepts. Rego et al. claim that the relationship between bioethics and ethical theories is the same relationship between biology and medicine, that is, ethics can be considered the foundation of bioethics and does not operate independently (Rego et al., 2020). Schramm proposes that "the legitimation of ethical action would only be a secondary elaboration of something that actually belongs to human biology" (Schramm, 1994, p.324), a thought that agrees with the statement that "all ethics is, first and fundamentally, a bioethics" (Schramm, 1994, p.324). As explained above, there are some contradictory and/or ambiguous perspectives. Thus, Siqueira-Batista (2020) proposes the (bio)ethical spelling, with the aim of overcoming such differences.

Based on these considerations, the objective of this essay is to expose the foundations and applications of (Bio)ethics for all beings - ethical current now being elaborated -, according to the works already published by its proposer.

\section{Methods}

Bibliographic research consists of a study based on published works, with the aim of exploring the theoretical contributions published on a given topic. From this research, an instrument can be created for use in any type of study: "In the bibliographic research, the researcher will survey the knowledge available in the area, identifying the theories produced, analyzing them and evaluating their contribution to help understand or explain the problem under investigation". (Köche, 2011, p. 122).

The narrative literature review aims to explore a specific subject, and may have a theoretical or contextual perspective (Rother, 2007) This strategy is not performed through systematic selections in bibliographic searches, it being possible to select studies at the author's discretion (Matos, 2015): "Review articles, as well as other categories of scientific articles, are a form of research that uses bibliographic or electronic information sources to obtain research results from other authors, in order to theoretically support a certain objective" (Rother, 2007, p.1).

Thus, this study consists of a narrative bibliographic review, in which a bibliographic survey was carried out on the topic (Bio)ethics of all beings, works by the author of the current, Rodrigo Siqueira-Batista, as well as works sent as a suggestion by him. author. 


\section{Results and Discussion}

\subsection{The fundamentals}

The (Bio)ethics of all beings is composed of some basic concepts that will be presented in this topic. They are: quiddity, totality, interdependence and laic compassion.

Nicola Abbagnano defines quiddity as a necessary essence, that is, what makes something what it is in essence, referring to living and non-living beings. The author also defines it as "essence in general, or to refer to a way of understanding essence” (Abbagnano, 2007). It is also worth mentioning São Tomás de Aquino thoughts: “(...) what the thing is established by in its own genus or species is what is meant by the definition indicating what the thing is, hence the name of essence is transformed by philosophers into the name of quiddity" (St. Thomas Aquino, 2005, I, 5).

From the conception of quiddity as an essential condition of reality, it is assumed that all beings, living and nonliving, are part of a space of ethical consideration (Siqueira-Batista, 2020). Different metaphors, coming from religion, philosophy or science, described quiddity as a conception of essential equality for all beings (Siqueira-Batista, 2008). From what has been exposed, it is possible to understand that all beings, living and non-living, have an essential prerogative that equals them, quiddity, that is, it can be said, with Siqueira-Batista (2020), that they are endowed with essential equality.

When considering all beings from the perspective of essential equality, from the concept of suchness, everything that exists can be conceived in terms of a totality (Bohm, 1992), according to the fundamental concept of the (Bio)ethics of all beings. The idea of totality can be understood, as highlighted by Siqueira-Batista (2020), from the Greek notion of phýsis, which refers to the "totality of everything that is" (Bornheim, 2008; Jaeger, 1952). In this sense, physicist David Bohm also defines totality as follows:

"(It is) misleading and undoubtedly wrong to suppose, for example, that each human being is an independent reality that interacts with other human beings and with nature. Rather, these are all projections of a single totality. (...) Failing to take this into account must inevitably lead the one who leaves it to serious and persistent confusion in everything they do" (Bohm, 1992, p. 275).

According to the defitions above, it is understood that all beings, living and non-living, are part of a single totality, which does not mean only the sum of all beings; more than that, this, the unique totality, also encompasses the relationship between beings, from which emerges the notion of interdependence of everything that exists, the third concept of (Bio)ethics for all beings (Siqueira-Batista, 2020). The foundation of interdependence can be found in the deep ecology of the philosopher Arne Naess, who states that the world is not formed from a "collection of isolated objects", but rather from a "network of phenomena" that are interdependent and interconnected (Naess, 1973). Akin to Naess, physicist Novello states that "no physical process is isolated. An event, every occurrence, has an intimate bond with its neighborhood" (Novello, 2005, p. 26).

From the above grounds - quiddity, totality and interdependence - it is understood that some bioethical references need to be revised, as they only consider Homo sapiens (and, in very special situations, some non-human animals) as subject to moral consideration (Siqueira-Batista, 2020). According to these concepts, the value of everything that exists must be recognized, which requires that ethical action be based on laic compassion, originally formulated in 2006 (Siqueira-Batista, 2006), which is presented as the fourth essential concept of Siqueira-Batista proposal. The first step in the exercise of laic compassion is to assume the quiddity of all beings, recognized in their totality in an unequivocal perspective of interdependence. According to the author, when an equal is launched in time and space, the attitude adopted towards it is one of "unrestricted receptivity", which is somehow expressed in the conception of unconditional Derridian hospitality, which concerns the acceptance of everything and any being, before any judgment or determination (Derrida, 2003; Siqueira-Batista, 2008; 2020):

"Pure and unconditional hospitality, hospitality itself opens up, it is open in advance to those who are neither 
expected nor invited, to those who arrive as a visitor, absolutely foreign, as an unidentifiable and unpredictable arrival, as a totally Other. Let us call this hospitality a visitation and not an invitation" (Derrida; Habermas, 2004, p. 188).

From these conceptions comes the support that is established between beings involved, which consists in the reception of the constitutive equality of all beings, without judgment. It is worth emphasizing that a paternalistic stance should not be used, as this unrestricted acceptance of the other does not assume that the recipient has a submissive position to the recipient (Siqueira-Batista, 2004, 2020). In this way, the exercise of laic compassion is in perfect harmony with what Brandon proposes:

“(...) offering people a home, opening the doors that were previously closed to them, asking more than answering. It means becoming highly sensitive to the other person's situation and feelings. It means listening with all your being and giving, if possible, what is relevant and appropriate to the relationship, not evaluating it with your own judgments" (Brandon, 1976, p. $51)$.

Therefore, it is necessary to compose the concepts of quiddity, totality, interdependence and laic compassion in order to understand the (Bio)ethics of all beings. Siqueira-Batista presents the terms in the following diagram (Figure 1).

Figure 1. Fundamental concepts of (Bio)ethics for all beings.

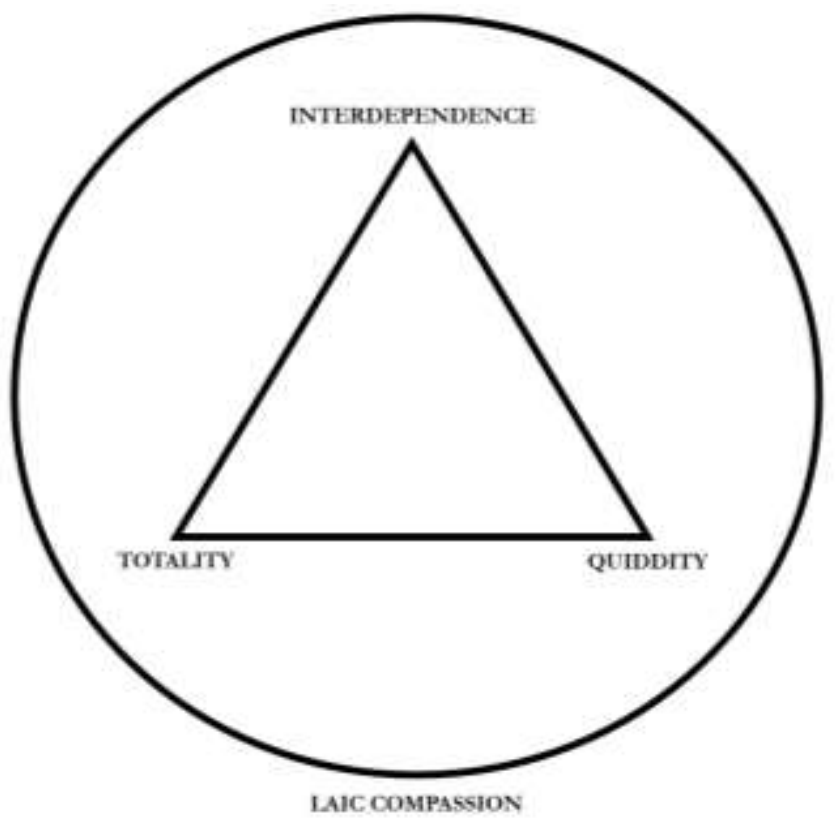

Source: (Siqueira-Batista, 2020)

It is understood, that the concepts of interdependence, totality and quiddity are related and give due support to the exercise of laic compassion, which is understood as the support, without judgment, of all beings, based on an equal acceptance of their conditions of existence (Siqueira-Batista, 2009; Siqueira-Batista, 2020).

\subsection{Proposed Applications}

(Bio)ethics for all beings can guide the approach to ethical conflicts in different fields. In this section, three topics will be presented in which (Bio)ethics for all beings can be applied: the end of life (euthanasia), environmental ethics and public health (in this study, using the cut-off in Primary Health Care). 


\subsubsection{End of life: euthanasia}

Euthanasia, or "good death", has been a topic that has been widely discussed nowadays. Its meaning goes back to the "abbreviation of the process of dying of a sick person, by action or non-action, with the ultimate objective of alleviating great and unbearable suffering" (Siqueira-Batista, 2006).

The decision for euthanasia is usually based on reducing the suffering of an individual and offering a dignified end of life. This debate is based on some principles: and the principle of sacredness of life (PSV), the principle of quality of life (PQV) (Rego et al., 2020) and the principle of respect for autonomy (PRA), recognizing the link of these last two (SiqueiraBatista, 2009). The PSV admits that life is a sacred good, that is, it cannot be interrupted even by the express desire of its owner. For Schramm, the PSV “considers human life unavailable to the subject of that specific life, and therefore one should respect the so-called intrinsic finalism of nature or the divine purposes without trying to oppose it" (Schramm, 2009, p. 337). Therefore, this principle indicates a stance against euthanasia. The PRA is the main principle that defends the practice of euthanasia, as it states that the person, when autonomous, has free choice related to their own life, including putting an end to it, especially in situations of extreme suffering (Siqueira-Batista, 2009). The PQV also supports the arguments in favor of euthanasia, as it claims that there is a value to life, but only if it has a degree of historically and culturally constructed sociocultural qualities accepted by the individual who owns it (Siqueira-Batista, 2009).

Siqueira-Batista argues that, with the condition of an incurable and intractable suffering, faced with the subject's decision not to profane his life, preventing it from fading into intense martyrdom, it means the attribution of a high value to it. Therefore, in this situation, dying can mean an act of affection for existence itself, placing it in a sacred dimension (SiqueiraBatista, 2009; Siqueira-Batista, 2004). When thinking about the principle of laic compassion, which means welcoming a being who needs support, especially in situations where autonomy is limited, seeing them as equals and providing conditions to carry out a minimum of self-determination to decisions, the practice of euthanasia can be an act of unconditional support for those who suffer (Siqueira-Batista, Schramm, 2009).

\subsubsection{Environmental Ethics}

Planet Earth has been going through an environmental crisis, which makes necessary - among other essential measures - a bioethical discussion with the objective of changing the relationship of human beings with nature (Boff, 2014; Leal, 2020). The current relationship is responsible for several disturbances and imbalances, which can cause various risks to humanity, such as an increase in the number of infectious diseases, scarcity, hunger, accidents caused by exacerbated exposure to heat, cold and sunlight, among others (Freitas, 2003; Loyal, 2020). As explained above, (Bio)ethics for all beings has as one of its foundations, quiddity, which recognizes that all beings have an essential equality, and the bearers of this equality are human and non-human beings, living and non-living, that is, everything that makes up nature, which dates back to the idea of the Greek physis, as mentioned (Siqueira-Batista, 2020; Siqueira-Batista et al., 2009). The foundations mentioned in the first topic - quiddity, totality and interdependence - meet with a change in the relationship with all beings, with total support and acceptance. According to Siqueira-Batista et al. (2009):

"The rational understanding that all beings can be united in terms of totality and interdependence makes it necessary to review the usual ethical references, which, as a rule, concern only human life - at best, other animals... - in response to the unequivocal recognition of the value of everything that exists, which becomes manifest, in ethical terms, in the unconditional acceptance, presupposition of laic compassion (...)" (Siqueira-Batista, 2009, p. 188, emphasis added).

Thus, it is necessary to question the possibility of maintaining environmental preservation in the current capitalist system, which is directly related to the exploitation of the planet (Boff, 2010). Arne Naess proposed the term deep ecology, mentioned earlier in this work, which emerged in the debate on ecocentrism. This concept is opposed to technocentrism, 
questioning the need for consumer goods (Sousa \& Sousa, 2018). Hans Jonas also questions the preservation of the planet of the capitalist system in his work The Principle of Responsibility, since, according to the author, this system promotes excessive consumption, leading any social body to its total disintegration (Jonas, 2006; Sousa \& Sousa, 2018).

In this way, (Bio)ethics for all beings, applied to the environmental discussion, allows to support the change of attitude towards nature, recognizing it for its intrinsic and not merely instrumental value, proposing an "ecocentrism" instead of "anthropocentrism" (Siqueira-Batista et al., 2009).

\subsubsection{Public Health / Primary Health Care}

Primary Health Care usually consists of the user's first contact with the Unified Health System (UHS), so it is a level of care that should offer care, affection and welcoming (Giordani et al., 2020; Mendes, 2011). Health professionals, including those working in PHC, are constantly faced with bioethical conflicts, which were deliberated under the light of principlism principles of autonomy, beneficence, non-maleficence and justice - but it is not enough for debates in this level of attention (Beauchamp \& Childress, 2013; Oliveira \& Siqueira-Batista, 2019). According to Oliveira and Siqueira-Batista: "Bioethical problems in PHC/ESF - despite their non-recognition - occur daily in health units that take care of families and communities, hindering the production of health care" (Oliveira \& Siqueira- Batista, 2019, p. 364).

Zoboli and Fortes carried out a classic study in 2004, in which the main bioethical conflicts present in PHC were exposed, organized into three categories, namely: (1) ethical problems in relationships with users and family; (2) in team relationships; and (3) in the relationships with the organization and the health system. (Zoboli \& Fortes, 2004). As for the first category, the lack of adequate "listening" to users was observed, in order to accommodate their demands. Therefore, while they were in need of care, they received procedures and norms. When professionals are bound by procedures, norms and routines, they end up seeing the user as a mere object, ignoring the fact that the user has the ability to lead his own life, which in addition to the obvious needs, also has desires, values, knowledge and potency (Merhy et al., 2014; Merhy \& Feuerwerker, 2009). Regarding the second category, Zoboli and Fortes report that, due to the incorporation of professionals from different specialties, there is a conflict of knowledge, making it difficult to assign functions between them; they also point out that conflicts stand out so intensely that professionals end up neglecting the attention to users. With regard to the third category, the authors highlight the bureaucracy found for efficient communication between the different health sectors, often requiring the personal contact of professionals for professional communication, as well as some structural difficulties of the UHS (access to health services, structural problems and work overload for health professionals) (Zoboli \& Fortes, 2004). Similar results were obtained by Simas et al. (2016) and Vidal et al. (2021). These problems result from the scrapping of the UHS, visible to users and health professionals, as well as presented by Silva, Batista and Santos (2019). The authors present the trajectory of the UHS, drawing an overview of health policy in Brazil, and conclude that there is a dismantling of the Unified Health System, favoring the private sector. The authors also emphasize the need to maintain the resistance and struggle to maintain the UHS, based on social movements with the participation of the community and health professionals (Silva et al., 2019). Recently, one of the important issues in terms of bioethical conflicts found in PHC is with regard to the care of the autistic subject, as discussed by Possamai, as related challenges: lack of knowledge about autism; screening and early diagnosis; and to therapeutic intervention. (Possamai, 2021a; Possamai, 2021b).

When UHS users arrive at the PHC, they need to be welcomed, taking into account the concept of equity, that is, all beings have an essential equality and, therefore, everyone needs a careful and compassionate look. According to SiqueiraBatista, when an action is launched in time and space, an action of "unrestricted receptivity" must be adopted (Siqueira-Batista, 2008, 2020) - as mentioned earlier in this study -, based on the concept of unconditional hospitality, that is, acceptance of any being, without judgment or determination (Derrida, 2003; Faria \& Siqueira-Batista, 2020; Siqueira-Batista, 2020). Then, users 
can be included in the list of beings who need an address, and health professionals need to welcome them as someone who offers shelter and protection.

\section{Final Considerations}

The present study proposed to present the (Bio)ethics of all beings, its foundations and their applicability. In this way, it was shown that the used spelling aims to make an intersection of ethics with bioethics, making it possible to contemplate their convergences and divergences. It is essential that there is an understanding of the aforementioned foundations, as it is understood that quiddity means the essential equality of all beings, which are connected to each other, being part of a totality, in a relationship of interdependence. From this conception, it is possible to face the world in a different way, promoting more care for other beings, in order to act following the concept of laic compassion, that is, with affection, protection and acceptance.

This bioethical model can be applied in several fields. In this study, the usefulness in the debate about the end of life (euthanasia), in environmental ethics and in public health (such as APS) was exemplified. However, the (Bio)ethics of all beings can be applied to different fields, from its theoretical deepening and the philosophical reflection in it, due to the proposition of a change of view in relation to the other, from an interventionist perspective to an interactionist - the first, commonly found in the capitalist system, aiming at exacerbated consumption of resources -, being this one alive or not, human or non-human, therefore contemplating the whole world that wonderfully presents itself.

Thus, more studies are necessary to be carried out on the (Bio)ethics of all beings, applying this bioethical proposal, its foundations - quiddity, totality and interdependence - and its moral principle - laic compassion - to situations of existing inequalities in society with the objective of identifying, guiding and, perhaps, alleviating the ethical conflicts existing in today's society.

\section{References}

Abbagnano, N. (2007). Dicionário de Filosofia. In Martins Fontes (5th ed.). Tradução da $1^{\circ}$ edição brasileira coordenada e revista por Alfredo Bossi; revisão da tradução e tradução dos novos textos Ivone Castilho Benedetti.

Aquino, T. de. (2005). O ente e a essência (Trad. de Carlos Arthur do Nascimento (ed.); 2nd ed.). Vozes.

Beauchamp, T. L., \& Childress, J. F. (2013). Princípios de Ética Biomédica (3rd ed.). Edições Loyola.

Boff, L. (2010). Cuidar da Terra, proteger a vida: como evitar o fim do mundo. Record.

Boff, L. (2014). Saber Cuidar: ética do humano - compaixão pela terra (20th ed.). Vozes.

Bohm, D. (1992). A totalidade e a ordem implicada: uma nova percepção da realidade. Cultrix.

Bornheim, G. A. (2008). Os filósofos pré-socráticos. Cultrix.

https://filosoficabiblioteca.files.wordpress.com/2013/10/bornheim-os-filc3b3sofos-prc3a9-socrc3a1ticos.pdf

Brandon, D. (1976). Ajuda pelo Zen-Budismo. (Trad. de Júlio César Assis Küll \& José Sidnei Pereira). Pensamento.

Derrida, J. (2003). Questão do estrangeiro: vinda do estrangeiro. In Tradução de Antonio Romane (Ed.), Anne Dufourmantelle convida Jacques Derrida a falar da hospitalidade. (Anne Dufou). Escuta.

Derrida, J., \& Habermas, J. (2004). Le concept du 11 septembre. Éditions Galilé.

Faria, F. G., \& Siqueira-Batista, R. (2020). (Bio)ética e população em situação de rua: entre Agamben e Derrida. Revista Bioética, $28(4)$, 628-636. https://doi.org/http://dx.doi.org/10.1590/1983-80422020284426

Freitas, C. M. (2003). Problemas ambientais, saúde coletiva e ciências sociais. Ciência \& Saúde Coletiva, 8(1), 137-150. https://doi.org/https://doi.org/10.1590/S1413-81232003000100011

Giordani, J. M. do A., Unfer, B., Merhy, E. E., \& Hilgert, J. B. (2020). Acolhimento na atenção primária à saúde: revisão sistemática e metassíntese synthesis. Revista de APS. https://www2.ufjf.br/ppgsaudecoletiva/wp-content/uploads/sites/143/2021/03/16690-Texto-do-artigo-114145-1-6-20191116-PRL.pdf 
Goldim, J. R. (2004). Definição de Bioética - Fritz Jahr 1927. Bioética. https://www.ufrgs.br/bioetica/bioet27.htm

Goldim, J. R. (2016). Definição de Bioética - Kennedy Institute of Ethics 1970. Bioética. https://www.ufrgs.br/bioetica/bioet70KIE.html

Jaeger, W. (1952). La teología de los primeros filósofos griegos (Trad. de José Gaos). Fondo de Cultura Económica.

Jonas, H. (2006). O princípio da responsabilidade: ensaio de uma ética para a civilização tecnológica. (PUC-Rio (ed.)). Contraponto.

Köche, J. C. (2011). Fundamentos de metodologia científica: teoria da ciência e iniciação à pesquisa. Vozes.

Leal, A. C. L. (2020). Ética da responsabilidade a serviço da sustentabilidade: uma proposta para superar crise ambiental. Universidade Federal do Rio Grande do Norte.

Mattos, P. de C. (2015). Tipos de revisão de literatura. Faculdade de Ciências Agronomicas UNESP Campus de Botucatu.

Mendes, E. V. (2011). As redes de atenção à saúde (2 ${ }^{\text {nd }}$ ed.). Organização Pan-Americana da Saúde.

Merhy, E. E. \& Feuerwerker, L. C. M. (2009). Novo olhar sobre as tecnologias de saúde: uma necessidade contemporânea. In E. Golberg \& A. C. de S. Mandarino (Eds.), Leituras de novas tecnologias e saúde. (pp. 29-74). Editora UFS.

Merhy, E. E., Feuerwerker, L. C. M., Gomes, M. P. C. \& Franco, T. B. (2014). Diálogos Pertinentes: micropolítica do trabalho vivo em ato e o trabalho imaterial. Novas subjetivações e disputas por uma autopoiese anticapitalística no mundo da saúde. Lugar Comum, 33-34, 89-103.

Mora, J. F. (1967). Diccionario de filosofia (Tomo I). Editorial Sudamericana. https://profesorvargasguillen.files.wordpress.com/2011/10/jose-ferrater-moradiccionario-de-filosofia-tomo-i.pdf

Naess, A. (1973). The shallow and the deep, long-range ecology movements: a summary. Inquiry, 16(1-4), 95-100. https://doi.org/https://doi.org/10.1080/00201747308601682

Naess, A. (1989). Ecology, community and lifestyle (D. Rothenberg (ed.)). Cambridge University Press.

Novello, M. (2005). Máquina do tempo: um olhar científico. (2nd ed.). Jorge Zahar Editor.

Oliveira, I. L. V. A. da C. \& Siqueira-Batista, R. (2019). Estratégia da saúde da família, biopolítica e biopoder: leituras de Foucault, pelas cores de Van Gogh. In J. C. de Castro \& M. Niemeyer-Guimarães (Eds.), Caminhos da Bioética II (II, pp. 363-395). Editora Unifeso. https://www.unifeso.edu.br/editora/pdf/694df6505dd21a75bd4ebff29891beb0.pdf

Possamai, V. R. (2021a). Care for autistic people in Primary Health Care: systematic review O Cuidado. Brazilian Journal of Development, 7(1), 1139111410. https://doi.org/10.34117/bjdv7n1-777

Possamai, V. R. (2021b). Transtorno do Espectro Autista: atualização. Revista Saúde Dinâmica, 1-16.

Potter, V. R. (1970). Bioethics, the science of survival. Perspectives in Biology and Medicine, 14(127), 127-153.

Rego, S., Palácios, M., \& Siqueira-Batista, R. (2020). Bioética para profissionais da saúde. (1st, 2 reimp ed.). Editora FIOCRUZ.

Reich, W. T. (1995). Encyclopedia of bioethics. (2nd ed.). New York: Macmillan Pub. Co.: Simon \& Schuster Macmillan; London: Prentice Hall International.

Rother, E. T. (2007). Revisão sistemática x Revisão narrativa. Acta PAul Enferm, 20(2), 1-2.

Schramm, F. R. (1994). Toda ética é, antes, uma bioética. Humanidades, 9(4), 324-331.

Schramm, F. R. (2009). O uso problemático do conceito 'vida' em bioética e suas interfaces com a práxis biopolítica e os dispositivos de biopoder. Revista Bioética, 17(3), 377-389.

Silva, A. C. da, Batista, J. H. S. \& Santos, W. C. M. (2019). Desmonte e sucateamento do SUS: o ataque neoliberal à política de saúde no Brasil. In Anais $7^{\circ}$ seminário FNCPS: Saúde em tempos de retrocesso e retirada de direitos (Vol. 1, Issue 1). https://www.seer.ufal.br/index.php/anaisseminariofncps/article/view/4009

Siqueira-Batista, R. (2004). Eutanásia e compaixão. Revista Brasileira de Cancerologia, 50(4), 334-340. http://www.inca.gov.br/rbc/n_50/v04/pdf/secao4.pdf

Siqueira-Batista, R. (2006). Às margens do Aqueronte: Finitude, autonomia, proteção e compaixão no debate bioético sobre a eutanásia. Escola Nacional de Saude Pública Sergio Arouca, FIOCRUZ.

Siqueira-Batista, R. (2008). Quantum bioethics: ethics for all beings. Ciencia \& Saúde Coletiva, 13, $1013-1015$.

Siqueira-Batista, R. (2009). A boa morte à luz da ética para todos os seres: o lugar da compaixão laica. In Vida, morte e dignidade humana (Vol. 1, Issue 1, pp. 341-362). GZ.

Siqueira-Batista, R. (2020). (Bio)ética para todos os seres: proêmio. In Caminhos da Bioética III (III, pp. 257-274). Editora Unifeso.

Siqueira-Batista, R., Gomes, A. P. \& Rôças, G. (2009). Ethics for all beings and deep ecology: an introductory dialogue with importance to public health. Caderno de Saúde Coletiva, 17(3), 559-573. 
Research, Society and Development, v. 10, n. 16, e264101622414, 2021

(CC BY 4.0) | ISSN 2525-3409 | DOI: http://dx.doi.org/10.33448/rsd-v10i16.22414

Siqueira-Batista, R. Motta, O. J. R. \& Gomes, A. P. (2021). Sob as bençãos de Jano: (Bio)ética - passado, presente e futuro. In A. C. V. Soeiro \& F. X. Palheta Neto (Eds.), Ensaios em bioética e cuidado em saúde. (pp. 23-60). GCOM Gráfica e Editora.

Siqueira-Batista, R. \& Schramm, F. R. (2009). A bioética da proteção e a compaixão laica: o debate moral sobre a eutanásia Ciência; Saúde Coletiva, 14(4), 1241-1250. https://doi.org/10.1590/S1413-81232009000400030

Sousa, M. C., \& Sousa, A. S. Ba. (2018). A formação do homem no contexto histórico da crise ambiental: a consciência ecológica frente ao pensamento reducionista. Kairós: R. Acadêmica Da Prainha, 15(2), 75-94.

Zoboli, E. L. C. P., \& Fortes, P. A. de C. (2004). Bioética e atenção básica: um perfil dos problemas éticos vividos por enfermeiros e médicos do Programa Saúde da Família, São Paulo, Brasil. Cadernos de Saúde Pública, 20(6), 1690-1699. https://doi.org/10.1590/S0102-311X2004000600028 